\title{
FACTORS AFFECTING EMPLOYEE PERFORMANCE THROUGH A MEDIATION OF JOB SATISFACTION. AN EMPIRICAL STUDY OF HOSPITALITY INDUSTRY IN HO CHI MINH CITY, VIETNAM
}

\author{
Mai Ngoc Khuong ${ }^{1, *}$, Nguyen Tran Nguyen Khai ${ }^{2}$, \\ Pham Thanh Huyen ${ }^{3}$, Nguyen Vo Hoai Thuong ${ }^{4}$, Nguyen Thi Minh Phuong ${ }^{5}$ \\ ${ }_{1,2,3,4,5}$ International University, Vietnam National University HCMC. \\ *Email: mnkhuong@hcmiu.edu.vn
}

(Received: December 24, 2015; Revised: January 07, 2016; Accepted: May 17, 2016)

\begin{abstract}
The research was conducted to explore the relationships between the factors of career development, team spirit, relationship at work, compensation and benefit, working environment, job stress and the factor of employee performance through a mediation of job satisfaction in Hospitality Industry in Ho Chi Minh City, Vietnam. Based on previous theoretical and empirical studies, the research conceptual framework and hypotheses were constructed. The primary data was collected from a questionnaire survey with 711 respondents. Multiple regression and Path analyses were conducted to test the research hypotheses, the results showed that career development, team spirit, relationship at work, compensation and benefit, working environment, and employee job satisfaction positively and directly impacted on employee performance. In addition, all factors indirectly influenced employee performance through job satisfaction. Hence, organizations operating in hospitality industry in Ho Chi Minh City should understand better employee expectations to efficiently and effectively improve and manage their human resources.
\end{abstract}

Keywords: Job satisfaction; employee performance; career development; team spirit; relationship at work; compensation and benefit; working environment; job stress.

\section{Introduction}

Concerned by the Party and the State in Ho Chi Minh City, Hospitality Industry develops and gains many considerable successfulness and achievements. Furthermore, it contributes positively to the region's economic development because of the increase in the number of total revenue in whole industry through many years.

Table 1. The revenue of hospitality industry in Ho Chi Minh city

\begin{tabular}{lccccccc}
\hline & & & & & \multicolumn{3}{c}{ (currency: billion VND) } \\
\hline Year & 2008 & 2009 & 2010 & 2011 & 2012 & 2013 & 2014 \\
\hline $\begin{array}{l}\text { Total } \\
\text { Revenue }\end{array}$ & 27,177 & 31,399 & 40,014 & 46,168 & 56,951 & 68,738 & 67,834 \\
\hline \hline
\end{tabular}

Source: Statistical Office in Ho Chi Minh City - 2014. 
In addition, the more increasing the economy develops, the higher the workforce demands, because employees play an important role in any organization's successful performance. However, the reality shows the human resources in hospitality industry in Ho Chi Minh City are in a state of "no lack of the manpower, but lack of the qualified human". It is reflected through a lack of serving professionalism to satisfy customers. Therefore, establishing the workforce with good job performance becomes very urgent and important with the key factors to create good employee performances, such as: career development, team spirit, relationship at work, compensation and benefit, working environment, job stress and job satisfaction (Judge et al., 2001; Swarnalatha and Sureshkrishna, 2014).

The objective of this research was to identify which important factors and how these factors affect job performance of employees working in hospitality industry in Ho Chi Minh City. Then, this study provided the practical evidences about these causal relationships and suggested some constructively specific recommendations for hospitality industry in Ho Chi Minh City to improve the higher job satisfaction and to lead the better employee performance.

\section{Literature review}

\subsection{Job Satisfaction}

One of most popular "job satisfaction" definitions said that job satisfaction is an association between three factors of psychology, physiology and environment together to create an employee to say truthfully that "I am satisfied with my current job." It means that job satisfaction presents a set of factors that cause a feeling of satisfaction (Hoppock, 1935). In addition, George and Jones (2008) stated that job satisfaction is an overall collection of emotions and beliefs that people can feel themselves during the period of working in their current company. Its level can be evaluated from "strongly satisfied" to "strongly dissatisfied" by employees in various impacts by their work characteristics, their supervisors and co-workers, their compensation and benefit as well as other internal and external factors.

When discussing about the elements of job satisfaction, it should be considered whether these elements can also cause job dissatisfaction. Hence, they can become two opposite and excludable phenomena and can cause a lot of no consensus among authors. To solve this problem, there is a theory to be recognized as the most solution, because it presents a main idea that employees are affected by the factors that cause both job satisfaction and job dissatisfaction in the workplace. Moreover, this theory separates the factors leading to job satisfaction (motivators) and the other factors leading to job dissatisfaction (hygiene factors) (Herzberg, 1976).

\subsection{Employee Performance}

Employee performance is really essential for any organization, because an organization's successfulness is dependent on creativity, innovation, satisfaction and commitment shown by its employees (Ramlall, 2008). Furthermore, good employee performances and productivity growth are important to stabilize the economy; to improve the better living standards, to grow up the higher wages, and to increase the available goods for consumption. Therefore, the general researches about individual employee's performance are important to social community (Griffin et al., 1981).

To explain further, some previous researchers clarified clearly the meanings of employee performance when they explained that some observable behaviors, which are done by employees in their jobs, are relevant to the target of an organization and are also known as job performance (Campbell et al., 
1990). Other researchers also stated that job performance is not the consequence of behaviors that is an inclusion of all behaviors of employees that can be observed when they actually engage (Campbell et al., 1993). Moreover, job performance is also defined as how work is important to employees, how employees master the important skills in their jobs and whether employees have the rights to determine the way his or her work (Hussin, 2011).

\subsection{Career Development}

Career development provides the beneficial opportunities for employees joining in job training and other types of professional development in order to achieve the better new advanced skills, to take greater responsibility at work, to improve their status, to earn higher income, all of which is aimed to promote their career. Organizations will become more effective and efficient if they have their professional employees know how to use skills and abilities in workplace to handle tasks well and complete their roles successfully so as to develop to their organizations (SHRM, 2013).

\subsection{Team Spirit}

Teamwork is also known as Team Spirit, is described as an organizational cooperation, is performed contemporaneously by all members in a team (Ingram and Desombre, 1999). It becomes an essential role for success and survival of an organization (Becton et al., 2002). To explain more specific, teamwork is understood as the collaboration between people in a group together, who gain certain specialization in capacities, abilities, knowledge and skills to perform task, are also responsible for the outcomes at the same time that their tasks are conducted (Manzoor et al., 2011).

Organizations usually use three primary phrases to develop their teamwork models. The first phrase comprises the task characteristics to be performed, the contextual elements to be taken place and the team spirit to be behaved by team members. The second one consists of cooperation and interaction of team members to complete the task performances well and to gain the set targets specifically. With regard to the final phrase of team outputs, it shows the results as well as the productivities are achieved by performances of team members.

\subsection{Relationship at Work}

In the workplace, the relationship between employees and their employers is considered as an associating perception between their supervisor's management and their overall working attitudes in their organization. In fact, management style is usually one of the most important problems to be concerned, because it can directly or indirectly affect employee performance as well as productivity and reputation of an organization.

There are many considerable components to build a good relationship at work. Firstly, the relationship with immediate supervisor, employees can be responded more effectively about their needs and problems by their immediate supervisor. Secondly, the communication between employees and senior management, this issue is also essential because effective communication from senior management can provide the workforce with direction. The third component is autonomy and independence, it means that organizations give their employees freedom and flexibility to decide how and when they complete projects because they can improve employee satisfaction and engagement; moreover, it also make their employees be responsible for their work outcomes as well as motivate them to produce better results. Finally, management's recognition of employee job performance through praise (private or public), awards and incentives is a cost-effective way to increase employee morale, productivity and competitiveness (SHRM, 2013). 


\subsection{Compensation and Benefit}

Compensation and benefit refers to all forms of financial returns, tangible services and benefits that all employees are received as an important and essential part in the employment relationship. Pay may be received directly in the form of cash (wages, merit increases, incentives, cost of living adjustments...) or indirectly through some benefits and services (pensions, health insurance, paid time off...) (Milkovich and Newman, et al., 2008).

In addition, compensation is mentioned including four main components such as being paid competitively with the local market; base rate of pay; opportunities for variable pay (bonuses, commissions, other variable pay; monetary rewards for ideas or suggestions) and stock options. With regard to benefit, there are six specific aspects of benefit evaluated by job satisfaction of employees, which consist of health care/medical benefits; paid time off; flexibility to balance life and work issues; defined contribution plans; defined benefit pension plans; family-friendly benefits (SHRM, 2013).

\subsection{Working Environment}

Working environment is known as physical geographical locations and surroundings in the workplaces. Working environment and employee job performance is interrelated (Hameed and Amjad, 2009; Akinyel, 2010). It means that employees are hard-working to improve the more effective performance and to increase the higher profitability and competitiveness in their organizations if they are provided a good working environment.

Therefore, organizations believe that their workforce will increase job satisfaction, raise productivity and performance if they really feel enjoyable and comfortable in their convenient working environment. There are many various components differently affecting the working environment factor, including: job security; organization's financial stability; the work itself; feeling safe in the work environment; overall corporate culture; relationships with co-workers; meaningfulness of the job; contribution of work to the organization's business goals; variety of work; organization's commitment to corporate social responsibility; to a diverse and inclusive workforce and to a "green" workplace (SHRM, 2013).

\subsection{Job Stress}

The term of stress is defined as a deviation from normal psychological or physiological functioning activities caused by urgent demands or immediate variations that individuals in organizations are suffered. It can be explained further that job stress is a particular awareness or feeling of each person about personal dysfunction as a result of perceived conditions or happenings in the workplace of any type of organization, where employees are demanded to change from normal or self-desired functioning due to opportunities or difficulties, or requirements relating to potentially important work-related outcomes (Cooper and Marshall, 1976; Beehr and Newman, 1978; Katz and Kahn, 1978; Ivancevich and Matteson, 1980; Schuler, 1980).

Besides that, job stress can occur when there are too many different organizational aspects; when the working time lasts continuously; when employees are not received any supports and changes from their organizations or any supports and directions from their supervisors and colleagues; finally, when there are too many conflicts with demands and pressures from their jobs. Consequently, job performance of employees declines under stressful situations. Moreover, the stressful problems from employees will decrease the quality productivity as well as organizational survival. Hence, stress at workplace becomes an essential concern to 
organization administrators (Deckard et al., 1988).

Previously, there were many researchers to prove both the direct and indirect impacts as well as the causal relationships among all factors mentioned in this study (Judge et al., 2001; Swarnalatha and Sureshkrishna, 2014). This study hypothized as follows:

$\mathrm{H}_{1}$ : Factors of career development, team spirit, relationship at work, compensation and benefit, working environment and job stress positively and directly affect Job Satisfaction.

$\mathrm{H}_{2}$ : Factors of career development, team spirit, relationship at work, compensation and benefit, working environment, job stress and job satisfaction positively and directly affect Employee Performance.

$\mathrm{H}_{3}$ : Factors of career development, team spirit, relationship at work, compensation and benefit, working environment and job stress positively and indirectly affect Employee Performance through Job Satisfaction.

\section{Methodology}

\subsection{Questionnaire Design and Data}

\section{Collection}

To test the proposed model and the given hypotheses, quantitative approach was mainly applied and a questionnaire survey was used to collect data. All items in the questionnaire were set with the Likert Scale's statement, basing on the five-point ranging from scale 1 to scale 5, equivalent to "strongly disagree" to "strongly agree". The target population of this study was employees working in hospitality industry in Ho Chi Minh City.

The researcher conducted the Pilot Test with $\mathrm{N}=30$ to calculate the reliability and find out potential problems of measurement in the questionnaire in order to revise immediately and prevent the research result from Halo Effect.

This study applied convenient sampling technique. The data were collected by two ways: (1) questionnaires were delivered directly to the target respondents and (2) the link of online questionnaire was sent to respondents through email and Facebook. After completing data collection, there were 711 valid respondents in total.

\subsection{Data Analysis}

SPSS software (Statistical Package for the Social Science) was used to analyze the data. Firstly, to explore the correlations of independent and dependent variables and to examine the reliability and validity of them, the study conducted Exploratory Factor Analysis (EFA) and Reliability Test. Secondly, Multiple Regression and Path Analysis were applied to find out the causal relationships between independent variables and dependent variable. Finally, basing on the analyzed results, the researcher could conclude the hypotheses in the study.

\section{Research findings}

\subsection{Profile of the Sample}

Nearly half of respondents are receptionists or waiters/waitresses working in hotels or restaurants. This position occupies $46.1 \%$ of total with 328 respondents. The position of low level manager accounts for $36.3 \%$ of total with 258 respondents. And the rest is middle level and high ranked manager position, including 125 managers with $17.6 \%$ of total respondents.

In term of gender, number of male employees and a number of female employees working in hospitality industry in Ho Chi Minh City are nearly equal. There are 342 male respondents with the proportion of $48.1 \%$ and 369 female respondents with the proportion of $51.9 \%$.

There are 487 single employees working in hotels and restaurants in Ho Chi Minh City while there are only 224 employees enjoying the married life. Employees who experience their jobs in hospitality industry less than 1 year: 128 people (18.0\%), from 1 - 3 years: 274 people $(38.5 \%)$, from 4 - 6 years: 206 people (29.0\%), from 7 - 10 years: 73 people $(10.3 \%)$ and from over 10 years: 30 people $(4.2 \%)$. 
As regards age, the age group from 23 30 years old has the highest proportion $(53.0 \%)$ with 377 respondents. The second and third portion is the group from $18-22$ years old and from $31-45$ years old with the ratio of $25.2 \%$ (equivalent to 179 respondents) and $16.9 \%$ (equivalent to 120 respondents). The rest of three groups contributes very small percentages in result total of the study, including 11 employees under 18 years old (1.5\%), 22 employees from 46 - 65 years old $(3.1 \%)$ and only 2 employees over 65 years old $(.3 \%)$.
The ratio of educational levels, employees who belong to two groups of college and university, have the two most proportions (274 people graduating from college and 263 people graduating from university). Their proportions are nearly equal, $38.5 \%$ and $37.0 \%$, respectively. Next group is vocational school with 98 employees, equivalently to $13.8 \%$. The group of post university has 40 respondents with the rate of $5.6 \%$. The final group consists of 36 employees graduating from high school with the smallest ratio in total (only 5.1\%).

\subsection{Factor Analysis and Reliability}

Table 2. Summary of independent variables

\begin{tabular}{lcc}
\hline \multicolumn{1}{c}{ Variables } & No. of Items & $\begin{array}{c}\text { Cronbach's } \\
\text { Alpha } \\
\text { (N = 711) }\end{array}$ \\
\hline JOB STRESS (JOSTRES) & 9 & .877 \\
TEAM SPIRIT (TEASPIRI) & 7 & .867 \\
COMPENSATION \& BENEFIT (COMBEN) & 6 & .861 \\
CAREER DEVELOPMENT (CARDEV) & 6 & .841 \\
RELATIONSHIP AT WORK (RELAWOR) & 3 & .728 \\
WORKING ENVIRONMENT (WORENVI) & 3 & .747 \\
\hline
\end{tabular}

There are two exploratory factor analyses (EFA) were conducted with Kaiser-MeyerOlkin and Barltlett's test of sphericity and Varimax Rotation of 64 items of independent variables and 17 items of dependent variables. The research collected the results of the KMO measure of sampling adequacy for both independent variables $(\mathrm{KMO}=.930)$ and dependent variables $(\mathrm{KMO}=.882)$. They were higher than the minimum value for a good factor analysis .60 [34]. Furthermore, Barltlett's test of sphericity was significant (Sig.=.000), demonstrating the sufficient correlation between the variables.

From the result shown in table 2, all independent variables were divided into 6 different components, including JOSTRES, TEASPIRI, COMBEN, CARDEV, RELAWOR and WORENVI. Factor loadings of remained items were from .467 to .755 , all of which were acceptable because of being higher than the level of minimum requirement at .40 (Hair et al., 2006). In addition, Cronbach's coefficient alpha value above .60 was proved to be acceptable by Pallant (2007), as a result, Cronbach's coefficient alpha values in the research were accepted because of their values greater than 70 .

With the regard to factor loadings of remained items of dependent variables in the table 3, they were separated 2 groups of EMJOSA and EMJOPER with their ranges 
from .536 to .777 and with their Cronbach's respectively.

coefficient alpha values were .850 and .789 ,

Table 3. Summary of dependent variables

\begin{tabular}{lcc}
\hline \multicolumn{1}{c}{ Variables } & No. of Items & $\begin{array}{c}\text { Cronbach's } \\
\text { Alpha } \\
(\mathbf{N}=\mathbf{7 1 1})\end{array}$ \\
\hline JOB SATISFACTION (EMJOSA) & 9 & .850 \\
EMPLOYEE PERFORMANCE (EMJOPER) & 4 & .789 \\
\hline
\end{tabular}

4.3. Factors affecting Job Satisfaction and Employee Performance

The research applied Pearson's Correlation Analysis and Linear Regression Analysis to explore the relationships between independent and dependent variables.

Table 4 showed that while four independent variables of CARDEV, TEASPIRI, RELAWOR and WORENVI and the mediate variable of EMJOSA had the highly positive correlations; COMBEN and JOSTRES had the lowly positive correlations with the dependent variable of EMJOPER. It means that if employees had the higher job satisfaction of career development, working environment, relationship at work and team spirit; they would perform their jobs with the higher level. On the other hand, because of some current compensation and benefit problems happened, this factor might not become the component impact dramatically on job performances; additionally, job stress suffered from employees could lowly affect the level of job performance.

Table 4. Correlations between variables

\begin{tabular}{|c|c|c|c|c|c|c|c|c|}
\hline & & EMJOPER & (1) & (2) & (3) & (4) & (5) & (6) \\
\hline (1) & CARDEV & .449 & 1 & & & & & \\
\hline (2) & TEASPIRI & .460 & 616 & 1 & & & & \\
\hline (3) & RELAWOR & .456 & .524 & .556 & 1 & & & \\
\hline (4) & COMBEN & .373 & .648 & .613 & .557 & 1 & & \\
\hline (5) & WORENVI & .433 & .567 & .595 & .530 & .598 & 1 & \\
\hline (6) & JOSTRES & .154 & .148 & .142 & .111 & .227 & .151 & 1 \\
\hline \multirow[t]{3}{*}{ (7) } & EMJOSA & .519 & .642 & .588 & .509 & .632 & .568 & .195 \\
\hline & Mean & 3.91 & 3.64 & 3.62 & 3.69 & 3.54 & 3.69 & 3.42 \\
\hline & Std. Deviation & .649 & .665 & .667 & .699 & .719 & .703 & .717 \\
\hline
\end{tabular}

Basing on the data's result, it showed all six independent variables are positively and directly correlated with EMJOSA. The vast majority of independent variables had the strong relationships with EMJOSA: CARDEV $\quad(r=.642, \quad p<.001), \quad$ COMBEN $(\mathrm{r}=.632, \mathrm{p}<.001)$, TEASPIRI $(\mathrm{r}=.588, \mathrm{p}<.001)$, WORENVI $(\mathrm{r}=.568, \mathrm{p}<.001)$, RELAWOR $(\mathrm{r}=.509, \mathrm{p}<.001)$; by contrast, JOSTRES $(\mathrm{r}=.195, \mathrm{p}<.001)$ had only the low relationship with EMJOSA.

In addition, the results of multiple 
regression showed that these factors had the positively and directly significant effects on EMJOSA with the explanation of $53.6 \%$ the variation of EMJOSA $\left(\mathrm{R}^{2}=.536\right)$. Furthermore, each independent variable had each different level of the regression coefficient, following: CARDEV $(\beta=.252$, sig.=.000), COMBEN $(\beta=.183$, sig.=.000), TEASPIRI $(\beta=.129$, sig. $=.000)$, WORENVI $(\beta=.118$, sig. $=.000)$, RELAWOR $(\beta=.066$, sig.=.022) and JOSTRES $(\beta=.044$, sig.= .045).

According to the result, EMJOPER was very highly correlated with EMJOSA ( $\mathrm{r}=.519$, $\mathrm{p}<.001)$; next, highly correlated with CARDEV $\quad(\mathrm{r}=.449, \quad \mathrm{p}<.001), \quad$ TEASPIRI $(\mathrm{r}=.460, \quad \mathrm{p}<.001), \quad$ RELAWOR $\quad(\mathrm{r}=.456$, $\mathrm{p}<.001)$ and WORENVI $(\mathrm{r}=.433, \mathrm{p}<.001)$; medium strongly correlated with COMBEN ( $\mathrm{r}$ $=.373, \mathrm{p}<.001)$; finally, very lowly correlated with JOSTRES $(\mathrm{r}=.154, \mathrm{p}<.001)$.

On the other hand, there were six of seven factors to have the direct effects on EMJOPER, including: CARDEV $(\beta=.097$, sig.=.029); TEASPIRI $(\beta=.130$, sig.=.003); RELAWOR ( $\beta=.185$, sig.=.000); COMBEN $(\beta=-.132$, sig. $=.002)$; WORENVI $(\beta=.092$, sig.=.019); EMJOSA $(\beta=.328, \quad$ sig. $=.000)$; whereas, JOSTRES was failed to achieve statistical significance affecting EMJOPER because of its significance sig.=.067 >.05. Moreover, with the value of R-Square was .350 , it means that the model explained $35.0 \%$ of the variance in EMJOPER.

\subsection{Indirect Effects of Employee Performance}

The indirect effect index of each independent variable on EMJOPER through EMJOSA was calculated by calculating the total effect of each independent variable on EMJOSA and EMJOSA on EMJOPER (Preacher and Hayes, 2008).

The effects of CARDEV, TEASPIRI, RELAWOR, COMBEN, WORENVI and JOSTRES on EMJOSA with $\beta=.252, \beta=.129$, $\beta=.066, \quad \beta=.183, \quad \beta=.118$ and $\beta=.044$, respectively; and the effect of EMJOSA on EMJOPER with $\beta=.328$; hence, the indirect effects of these independent variables on EMJOPER through EMJOSA were equivalent to $.083, .042, .022, .060, .039$ and .014 .

\subsection{Significance of the Indirect Effects}

Table 5. Direct, indirect, total causal effects

\begin{tabular}{lccccc}
\hline \hline \multirow{2}{*}{ Variables } & \multicolumn{3}{c}{ Causal Effects } & LL & UL \\
\cline { 2 - 4 } & Direct & Indirect & Total & & \\
\hline CARDEV & .097 & .083 & .180 & .0564 & .1108 \\
TEASPIRI & .130 & .042 & .172 & .0228 & .0642 \\
RELAWOR & .185 & .022 & .207 & .0059 & .0384 \\
COMBEN & -.132 & .060 & -.072 & .0382 & .0834 \\
WORENVI & .092 & .039 & .131 & .0209 & .0587 \\
JOSTRES & --- & .014 & .014 & .0022 & .0271 \\
EMJOSA & .328 & --- & .328 & & \\
\hline \hline
\end{tabular}


The results of the bootstrapping method recommended by Preacher and Hayes (2008) to test the significance of indirect effects or mediation were shown in above table 5. It provided the bootstrapped confidence intervals at $95 \%$. If there was a zero (0) to lie within the interval range between the lower boundary (LL) and the upper boundary (UL), there was no mediation or indirect effect with $95 \%$ confidence in the research. However, if a zero (0) did not appear between the LL and the UL, the research could conclude that the mediation or indirect effects were significant with $95 \%$ confidence (Preacher and Hayes, 2004).

From table 5, all indirect effects of six independent variables on EMJOPER through the mediation of EMJOSA were significant because there was not any zero (0) occurring between the LL and the UL. It could be explained further at $95 \%$ confidence,
CARDEV with .0564 (LL) and .1108 (UL); TEASPIRI .0228 (LL) and .0642 (UL); RELAWOR with .0059 (LL) and .0384 (UL); COMBEN with .0382 (LL) and .0834 (UL); WORENVI with .0209 (LL) and .0587 (UL); JOSTRES with .0022 (LL) and .0271 (UL).

\subsection{The Causal Effects of Employee}

\section{Performance}

Basing on the total effects of independent variables on dependent variable, both direct and indirect effects, and mediate variables summarized in table 5, EMJOSA had the strongest impact on EMJOPER $(\beta=.328)$, followed by RELAWOR ( $\beta=.207)$, CARDEV $(\beta=.180)$, TEASPIRI $(\beta=.172)$, WORENVI $(\beta=.131)$ and JOSTRES $(\beta=.014)$. In contrast, COMBEN provided the negative impacts on EMJOPER with $\beta=-.072$. In short, the total effect of the factors affecting employee job performance was $\mathbf{. 9 6 0}$.

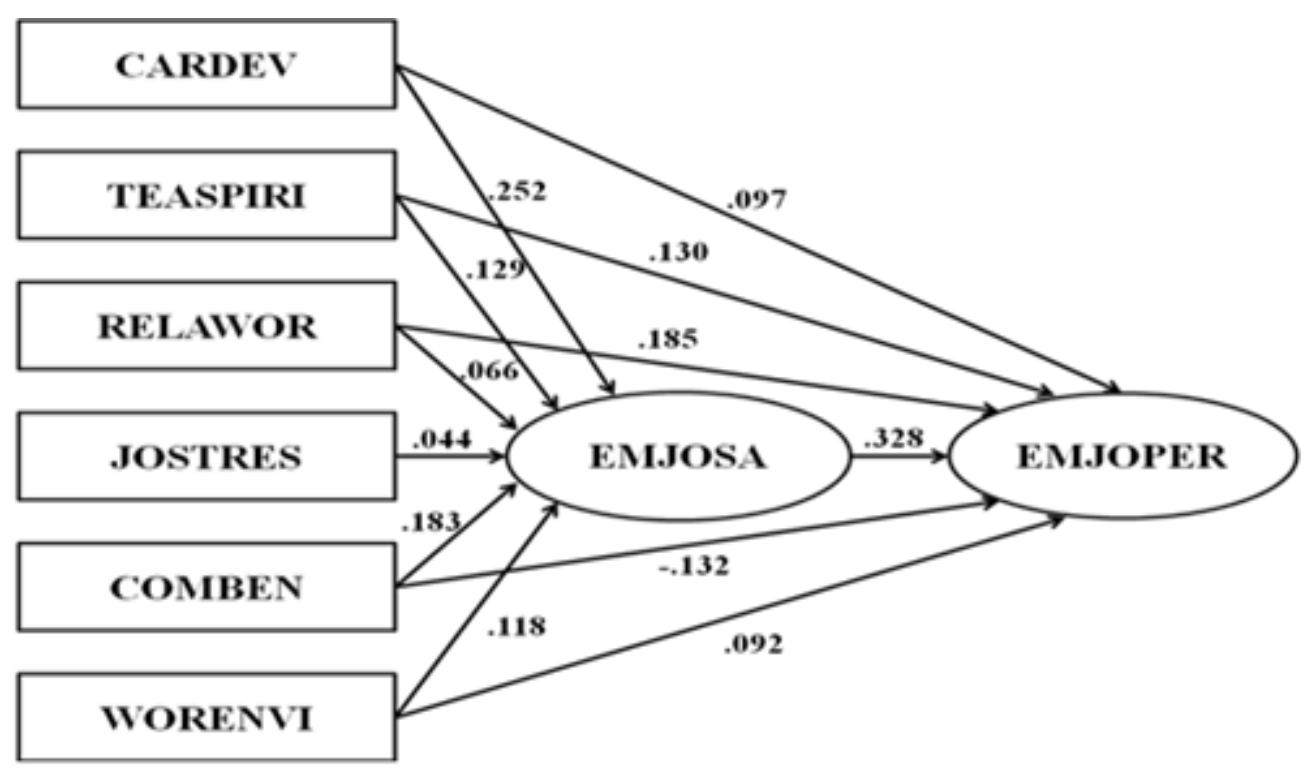

Figure 1. Path coefficients of the structural equation for hypothesis testing

\section{Discussions and recommendations}

\subsection{Discussions}

The research with its empirical results provided the positive explanation for the proposed model of conceptual framework and the appropriate prediction for current circumstances in human resources management in Hospitality Industry in Ho Chi Minh City, Vietnam. The research findings illustrated that the factors of career development (total $\beta=$ $.180, \mathrm{p}<.05$ ), team spirit (total $\beta=.172, \mathrm{p}<$ .05 ), relationship at work (total $\beta=.207, \mathrm{p}<$ .05 ), compensation and benefit (total $\beta=$ $.072, \mathrm{p}<.05$ ), and working environment (total 
$\beta=.131, \mathrm{p}<.05)$ directly and indirectly affected employee performance through job satisfaction. However, job stress did not directly affect performance but provided indirect effect $(\beta=.014, p<.05)$ to employee performance through job satisfaction. It means that employees working in Hospitality Industry in Ho Chi Minh City will perform the higher job productivity if they are more satisfied with the demands and expectations from their organizations.

This result was supported by some previous researches' demonstrations (Judge et al., 2001; Parker and Decotiis, 1983; Mansoor et al., 2011; SHRM, 2013; Manzoor et al. 2011; Musriha, 2013; Hussin, 2011; Parvin and Kabir 2011; Chei et al. 2014). These studies approved that the effects of six independent variables towards employee job satisfaction are significant and obvious. Moreover, the positive relationship between job satisfaction and employee performance was identified clearly. Furthermore, four factors of career development, team spirit, relationship at work and working environment were found to have the positive significance with job performances of employees.

However, there were some significant differences of the compensation and benefit factors and the job stress factor to be explored between the previous results and the result of this study. To explain furthermore, while compensation and benefit was found out to have the negative significance with employee job performance in this research findings, it was considered to have the positive relationship with employee job performance by Vrinda and Nisha (2015). Additionally, the previous studies of Bashir and Ramay (2010); Swalhah et al. (2013); Swarnalatha and Sureshkrishna (2014) showed that job stress has a negative relationship with job performance, because when stress occurs, it negatively affects the job performance of employees and if stress is lower, it will increase employee job performance. In contrast, in this research, the factor of job stress was discovered to have the positive relationship with employee performance, but its effect was not considerably significant.

In conclusion, the causal relationships between the factors of career development, team spirit, relationship at work, compensation and benefit, working environment and job stress and job satisfaction and employee performance are tested and confirmed. Almost research hypotheses were accepted, but only one (job stress) was not accepted. Hence, this research conceptual framework provided the empirical evidences to current situations of Hospitality Industry in Ho Chi Minh City.

\subsection{Recommendations for Hospitality}

\section{Industry in Ho Chi Minh City}

From the research findings, the study contributes some proposed constructive recommendations to organizations and their managers working in hospitality industry in Ho Chi Minh City.

This empirical study provides the practical proof on the causal relationships between the factors of career development, team spirit, relationship at work, compensation and benefit, working environment, job stress and employee job satisfaction as well as employee job performance to raise up the awareness of business organizations operating in hospitality industry in Ho Chi Minh City about the order level of these factors impacting on their employees' job satisfaction and job performance.

Organizations should be seriously interested in elements creating their employees' job satisfaction: to satisfy with current job when workload and work assignment is divided appropriately, to receive salary and benefits fairly, to satisfy with management and supervision style at work, to have many promotion opportunities, to feel safe and secure in working environment. This study proves that employees will perform their job at higher level 
when they feel really satisfied with their jobs in current organizations.

To explain further, by recognizing and understanding reasons why employees are satisfied with their careers, organizations can access closer to their target of increasing employee job performance. Firstly, to build relationships at work becomes better when employees can communicate effectively with their co-workers, immediate supervisors and also feel easier and more convenient with management style at work. Secondly, to provide job specific training courses, to help in advancing in employees' career, to create opportunities in using skills and abilities in learning and growing professional specialization, all of which make employees satisfy with their company's policies of career development. Thirdly, with team spirit that never gives up in difficult challenges and pressures, always try to adapt crisis situations, look out the problems and deal well with the best solutions together, it will become the strong cohesion in the cooperating relationship between team members in group together. Next, working environment is built sustainably by mounting the social responsibility, (including in balancing financial performance with contributions to the quality of life of employees, to local community and society at large); as a result, it will also increase employee job satisfaction. In short, when almost above elements are implemented by organization to meet the demands of employees, it is believed that the rate of job dissatisfaction will decrease and the rate of job performance will increase higher and higher in that organization.

In addition, with the regard to compensation and benefit, it seems not to be concerned and focused by organizations working in hospitality industry in Ho Chi Minh City because this empirical research shows that the compensation and benefit factor negatively affects employee performance. Hence, this problem should be more improved by organization so that job performance of employees can be grown up substantially. Managers should say that recognition of good employee job performance is essential with specific actions such as to pay salary competitively with local market, to pay fair amount for the work, to create opportunities for reasonably variable pays and rewards (for example: bonuses, monetary or non-monetary rewards for creative ideas or new suggestions or effective contributions).

In conclusion, all above proposed recommendations and suggestions may be suitable for some business organizations in hospitality industry in Ho Chi Minh City to improve and develop their better human resources management. Increasing at the rate of employee job performance means that the service quality and productivity of organizations will also increase in achieving the higher total of annually profit and revenue.

\section{Conclusion}

This study is conducted in order to identify and investigate the causal relationships between the six factors of career development, team spirit, relationship at work, compensation and benefit, working environment, job stress and the factor of employee performance through the mediate factor of job satisfaction, all of which are surveyed by employees working in hospitality industry in Ho Chi Minh City. Basing on the previous theoretical as well as empirical studies, the research constructs its conceptual framework and hypotheses, which are acceptable after the analysis of collected data. From the research findings, the study shows both of the significantly positive effects and the significantly negative effects of independent variables on employee performance through job satisfaction, because these factors become the effective tools to predict, explore and explain job satisfaction 
and job performance of employees working in hotels/restaurants in Ho Chi Minh City.

Hence, business organizations in hospitality industry in Ho Chi Minh can apply the empirical result of this research into their organization and management systems to understand deeply and then to meet exactly the requirements as well as the expectations from their employees. Always, operating and managing the workforce is essentially important for any organization to maintain and to develop the organization's sustainable survival. With the worthwhile and accurate and meticulous information, this result will help organizations and their managers to change and implement the better improving strategies and plans to manage and develop their human resources in the nearly developing projects in future.

\section{REFERENCES}

Akinyel S. T. (2010). The influence of work environment on workers' productivity: A case study of selected oil and gas industry in Lagos, Nigeria. African Journal on Business Management, Vol.4, No. 3, pp. 299-307.

Bashir U. and Ramay M. I. (2010). Impact of Stress on Employees Job Performance: A Study on Banking Sector of Pakistan. International Journal of Marketing Studies, Vol. 2, No. 1.

Becton C., Wysocki A. and Kepner K. (2002). Building Teamwork and the Importance of Trust in a Business Environment. Food and Resource Economics Department, Florida Cooperative Extension Service, Institute of Food and Agricultural Sciences, University of Florida, 2002.

Beehr T. A. and Newman J. E. (1978). Job stress, employee health, and organizational effectiveness: A facet analysis, model and literature review. Personnel Psychology, Vol. 31, pp. 665-699.

Campbell J. P., McCloy R. A., Oppler S. H. and Sager C. E. (1993). A theory of performance. Personnel selection in organizations, pp. 35-70. San Francisco, CA: Jossey-Bass.

Campbell J. P., McHenry J. J. and Wise L. L. (1990). Modeling job performance in a population of jobs, Personnel Psychology, Vol. 43, pp. 313-333.

Chei C. H., Yee H. C., Men L. P. and Bee L. L. (2014). Factors affect Employees' Performance in Hotel Industry. Bachelor of Business Administration, Tunku Abdul Rahman University.

Cooper C. L. and Marshall J. (1976). Occupational sources of stress: A review of the literature relating to coronary heart disease and mental ill health. Journal of Occupational Psychology, Vol. 49, pp. 11-28.

Deckard G. J., Rountree B. H. and Hicks L. L. (1988). Nursing Productivity: A qualitative View of performance. Nurs Economics, Vol. 6, pp. 184-188.

George J. M. and Jones G. R. (2008). Understanding and Managing Organizational Behavior, $5^{\text {th }}$ ed. Pearson/Prentice Hall, New Yersey, p.78.

Griffin R. W., Welsh A. and Moorhead G. (1981). Perceived Task Characteristics and Employee Performance: A Literature Review. Academy of Management Review, Vol. 6, No. 4, pp. 655-664. 
Hair J. F. J., Black W. C., Babin B. J., Anderson R. E. and Tatham R. L. (2006). Multivariate Data Analysis, 6th ed. New Jersey: Prentice Hall.

Hameed A. and Amjad S. (2009). Impact of office design on employees' productivity: A case study of banking organisations of Abbotttabad, Pakistan. Journal of Public Affairs, Administration and Management, Vol. 3, no. 1.

Herzberg H. F. (1976). Motivation-Hygiene Profiles, p. 20.

Hoppock R. (1935). Job Satisfaction. Harper and Brothers, New York, p.47.

Hussin A. B. (2011). The Relationship between Job Satisfaction and Job Performance among Employees in Tradewinds Group of Companies. Master of Human Resource Management, Open University Malaysia, 2011.

Ingram H. and Desombre T. (1999). Teamwork: comparing academic and practitioners' perceptions. Team Performance Management, Vol. 5, no. 1, pp. 16-22.

Ivancevich J. M. and Matteson M. T. (1980). Stress and work. Glenview, II1: Scott, Foresman.

Judge T. A., Bono J. E., Thoresen C. J. and Patton G. K. (2001). The Job Satisfaction-Job Performance Relationship: A Qualitative and Quantitative Review. Psychology Bulletin, Vol. 127, No.3, pp. 306-407.

Katz D. and Kahn R. L. (1978). The social psychology of organizations, $2^{\text {nd }}$ ed. New York: Wiley.

Mansoor M., Fida S., Nasir S. and Ahmad Z. (2011). The Impact of Job Stress on Employee Job Satisfaction: A Study on Telecommunication Sector of Pakistan. Journal of Business Studies Quarterly, Vol. 2, No. 3, pp. 50-56.

Manzoor S. R., Ullah H., Hussain M. and Ahmad Z. M. (2011). Effect of Teamwork on Employee Performance. International Journal of Learning \& Development, Vol. 1, No. 1.

Milkovich G. T. and Newman J. M. (2008). Compensation, $9^{\text {th }}$ ed. McGrawHill Irwin.

Musriha. (2013). Influence of Teamwork, Environment on Job Satisfaction and Job Performance of the Cigarette Rollers at Clove Cigarette Factories in East Java, Indonesia. Developing Country Studies, Vol. 3, no. 2.

Pallant J., SPSS Survival Manual: A Step by Step Guide to Data Analysis Using SPSS for Windows, $3^{\text {rd }}$ ed. Open University Press, 2007.

Parker D. F. and Decotiis T. A. (1983). Organizational Determinants of Job Stress. Organizational Behavior and Human Performance, Vol. 32, pp. 160-177.

Parvin M. M. and Kabir M. M. N. (2011). Factors Affecting Employee Job Satisfaction Of Pharmaceutical Sector. Australian Journal of Business and Management Research, Vol. 1, No. 9, pp. 113-123.

Preacher J. K. and Hayes A. F. (2004). SPSS and SAS procedures for estimating indirect effects in simple mediation models. Behavior Research Methods, Instruments and Computers, Vol. 36, No. 4, pp. 17-731. 
Preacher J. K. and Hayes A. F. (2008). Asymptotic and re-sampling strategies for assessing and comparing indirect effects in multiple mediator models. Behavior Research Methods, Vol. 40, No. 3, pp. 879-891.

Ramlall S. (2008). Enhancing Employee Performance through Positive Organizational Behavior. Journal of Applied Social Psychology, Vol.38, No. 6, pp. 1580-1600.

Schuler R. S. (1980). Definition and conceptualization of stress in organizations. Organizational Behavior and Human Performance, Vol. 25, pp. 184-215.

Society for Human Resource Management (SHRM). (2013). Employee Job Satisfaction and Engagement: The Road to Economic Recovery.

Statistical Office in Ho Chi Minh City. (2014). Economic and Social Annual Report in 2014.

Swalhah A. A., Irtima H. Zouby A., F. and Shaar J. (2013). The Relationship Between Job Stress And Job Performance Among Workers In Alisraa Hospital. Far East Journal of Psychology and Business, Vol. 12, No. 2.

Swarnalatha C. and Sureshkrishna G. (2014). A Study on Job Stress, Job Performance and Employee Job Satisfaction among Female Employees of Automotive Industries in India. Australian Journal of Basic and Applied Sciences, Vol. 8, No. 1, pp. 469-472.

Tabachnick B. G. and Fidell L. S. (2001). Using multivariate statistics, 4th ed. NewYork: HarperCollins.

Vrinda N. N. and Nisha A. J. (2015). The Impact Of Job Satisfaction On Job Performance. International Journal in Commerce, IT \& Social Sciences, Vol. 2, No. 2. 